\title{
Health Issues and Cruising in Covid-19 Era
}

\author{
Polyxeni Moira ${ }^{1 *}$, Dimitrios Mylonopoulos ${ }^{1}$, Elli Terzoglou ${ }^{2}$ \\ ${ }^{1}$ Professor University of West Attica \\ ${ }^{2}$ Assistant Professor University of West Attica
}

*Corresponding Author: Polyxeni Moira, Professor University of West Attica

\begin{abstract}
The cruise ship, as a means of public transport, is a modern "floating resort" that accommodates a large number of travellers, served by a large number of employees. In fact, this large group of people employees and travellers - is multicultural, as they come from several countries of the world with different cultures.

In this context, maintaining good health throughout cruising contributes greatly to the enjoyment of this form of maritime tourism activity and has significant economic, cultural and social benefits. In the present study, the importance of the health factor on the cruise ship is analysed with emphasis on the problems arising due to the corona virus pandemic (Covid-19).
\end{abstract}

Keywords: cruise ship, health, hygiene, tourism, Covid-19

\section{INTRODUCTION}

The cruise ship was at the centre of tourist interest in the early 1980s, when new ships, specifically designed for cruising, started being built (Starr, 1993:176). This was reinforced by aggressive

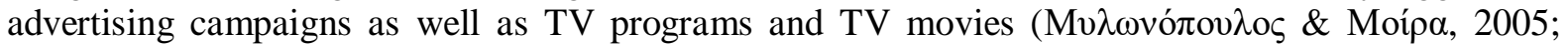
Wood, 2000), such as the well-known "The Love Boat" that helped to popularize the concept of cruising and make it more attractive. This increase in demand for cruising encouraged companies to build bigger vessels. In the 1990s, ships with a carrying capacity of about 2,000 passengers began to be built. This is the generation of cruise ships that are characterized as "Megaships" and belong to the "Second generation" of cruise ships. A typical example, the "Sovereign of the Seas", characterized as a "floating resort", symbolizes the change in the philosophy of cruising from a simple pleasure trip to a "self-sufficient - complete holiday experience" (Foster, 1994:141-142). This generation of cruise ships is dominated by the element of luxury and the hotel-type first rate class services, i.e. accommodation, catering, entertainment, day and night activities and guided tours to the ports

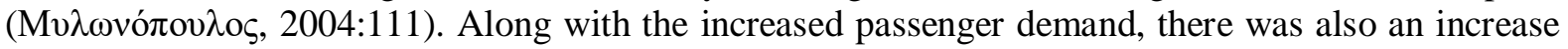
in the tendency to build new ships.

After the year 2000, modern cruise ships are characterized by their even larger size ranging from 150,000 GRT (Gross Registered Tonnage) to 225,000 GRT etc. and a carrying capacity from 3,000 to 6,000 passengers. In 2018, the total fleet of cruise ships amounted to 314 ships with a capacity of 537,000 passengers. There is also an increase in passenger traffic. According to the data from the Cruise Lines International Association (CLIA, 2019) for 2019, passengers amounted to 30 million, which generated 1,108,676 jobs. Demand for cruising in the decade $2005-2015$ increased by $68 \%$. There are 62 cruise companies, with 275 partners and 30,000 certified travel agents (CLIA, 2015).

The modern cruise ship is a small city. It offers easy access to some of the most popular destinations. For the passengers, the cruising experience is associated with a number of motives, i.e. gaining prestige, staying in a cosmopolitan and pleasant social environment, safety, high quality services, possibility to experience different destinations with ease and comfort, etc. Cruise ships offer the comforts of home, "away from home", rest, recreation, escape from everyday life. They offer organized vacations that cover the needs of the whole family and of people of different ages and

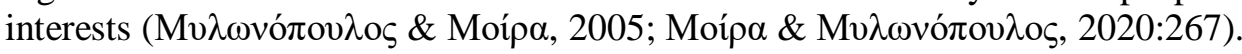

Cruising has proven to be a safe way for vacations. However, due to the massive number of passengers traveling to various parts of the world, there are serious risks to safety, health, and well- 
being. During cruising, travellers from different parts of the world, with different habits and hygiene rules meet and live together in often crowded, semi-enclosed environments, which facilitate the spread of diseases from person to person, or from food and water (Tardivel, White \& Kornylo Duong, 2019). Shared activities such as entertainment and banquets increase the likelihood of contact between travellers. In addition, the risk posed to travellers being exposed to infectious diseases increases, as well as the spread of infectious diseases by travellers boarding cruise ships from various ports, where

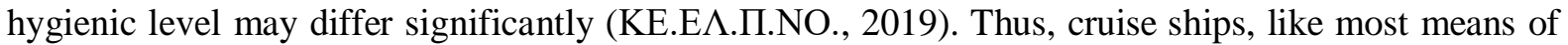
public transport, catering and recreation, are ideal places for the concentration, proliferation and spread of almost all pathogenic infectious microbes transmitted by humans, insects, arthropods, rodents, other animals, food, water, etc. (Jones - Hillier \& Comfort, 2016:27).

Cruise ship facilities are ideal for pathogenic germs to grow due to the physicochemical conditions created in them (temperature, humidity, pollutants) and the easy spread of pathogens by the passengers and the ship's crew. Typical is Dr. James Lind's statement, who, in 1747, reported that the number of sailors who died in wars, in shipwrecks, from starvation, fire, and in battle was much lower than those who died from diseases that occurred on board (Tröhler, 2003). Moreover, an epidemic gastrointestinal illness aboard a U.S. Navy ship, in 1997, resulted in 1,807 afflicted members, $43 \%$ of the crew (WHO, 2011; The Guardian, 2003a). The most common diseases on cruise ships are respiratory tract infections, gastrointestinal infections (such as norovirus) and other diseases that cannot be prevented by vaccination (except for the flu), such as chickenpox.

Very often, influenza outbreaks have been reported among passengers traveling by ship or plane, where conditions contribute to the rapid spread of the disease. It is known that international travelling influences significantly the epidemiology of influenza since it is the most important factor for the global spread of new strains of the influenza virus. A typical example is the outbreak of influenza A (H3N2) on a cruise ship in Sydney in 1997, which introduced this strain to the United States and

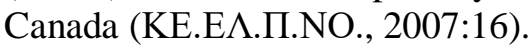

For these reasons, cruising as a tourist activity is directly linked to the risk of infectious diseases with consequences that are not limited only to those on board but also to the ports of embarkation disembarkation of travellers. For preventive healthcare reasons, every passenger should be treated as a prospective or potential carrier of infectious agents that may not get ill but can spread the infectious agent in the environment. A person becomes ill, when the infectious agent exceeds disease tolerance in number and quantity and the time required ranges from a few hours to several days. This is the main reason we are not able to immediately identify the source of infection.

To reduce the risk of infectious diseases on a cruise ship, a medical examination may be carried out during boarding in order to identify sick passengers and either prohibit them from boarding or put them in quarantine if they are allowed to board (Tardivel, White \& Kornylo Duong, 2019). Moreover, passengers / tourists should be aware of the potential risks they may face when traveling, so that they are prepared to react on a case-by-case basis. To deal with these risks, basic knowledge of personal hygiene, public health and nutrition is required by each individual, along with the protection measures that should be provided by the tourist operator organizing the leisure trip (Moíp $\alpha \&$ Mv $\lambda \omega v o ́ \pi \circ v \lambda \circ$, 2020:390).

The complexity of the consequences of the occurrence of infectious diseases on a cruise ship goes beyond the narrow boundaries of the disease outbreak area and requires action not only at a private level, but also at national and international levels. This is achieved through international cooperation on health and safety in tourism.

\section{The Health PARAMETER IN CRUISING}

According to the World Health Organization, from 1970 to January 2001, more than 100 epidemics were recorded on ships (cruise ships, merchant ships, ferries, warships, fishing vessels). However, most of these (83 cases) involved cruise ships (WHO/SDE/WSH/01.4, 2001; Rooney, et al. 2004; WHO, 2011). The reported cases related to legionnaires' disease, influenza, typhoid fever, salmonella, gastroenteritis (e.g. norovirus), E-coli, shigellosis, etc. According to the Centre for Disease Control and Prevention, between 2008 and 2014, 129,678 out of the 74 million cruise passengers in the Centre's control area developed gastrointestinal disorders and $10 \%$ of these cases were due to Norovirus (CDC, 2014).

The table below presents the outbreak cases on cruise ships from 2006-2019, falling on the responsibility of the American Centre for Disease Control and Prevention (CDC). 
Table1. Cruise ship epidemics (2006-2019)

\begin{tabular}{|l|l|l|l|}
\hline Year & Total & Passengers & Crew members \\
\hline 2019 & 14 & 1.440 & 116 \\
\hline 2018 & 15 & 1.099 & 78 \\
\hline 2017 & 21 & 2.450 & 85 \\
\hline 2016 & 23 & 2.378 & 126 \\
\hline 2015 & 23 & 2.458 & 112 \\
\hline 2014 & 14 & 3.354 & 205 \\
\hline 2013 & 22 & 2.249 & 136 \\
\hline 2012 & 34 & 5.079 & 463 \\
\hline 2011 & 23 & 1.834 & 137 \\
\hline 2010 & 37 & 6.799 & 302 \\
\hline 2009 & 30 & 3.800 & 397 \\
\hline 2008 & 39 & 3.465 & 278 \\
\hline 2007 & 42 & 4.228 & 349 \\
\hline 2006 & 54 & 6.567 & 648 \\
\hline
\end{tabular}

Source: Centre for Disease Control and Prevention (2019)

\section{Editing: The authors}

In case of an epidemic on a cruise ship, the cruise company must activate an "Outbreak Prevention and Response Plan" which includes specific actions, such as increasing the frequency of cleaning and disinfection on board, stopping the buffet service, isolating sick passengers and crew members in their cabins, informing the passengers about the epidemic, informing the passengers of the next itinerary of the cruise ship and informing the port and local authorities of the ports of call (Moípa \&

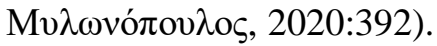

In the globalization era, when people and goods can move easily and quickly from country to country, it is possible for infectious agents to spread among populations of different geographical areas of the world. This phenomenon is reinforced by the latest climate changes on our planet (Sawchuk, 1993:875-892; Ewan - Bryant \& Calver, 1991; Walsh, Molyneux \& Birley, 1993:555-575; Goldstein \& Reed, 1991:193-196; Fujimori \& Shimura, 1987:112-144; WHO, 2003). Infectious diseases such as diphtheria, cholera, malaria, tuberculosis, which were unknown for many years in Europe, began to

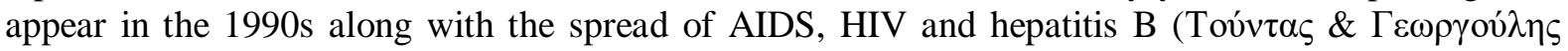
1998:482-493; WHO, 2003). New infectious diseases of animals, which threaten humans through the food chain (bovine spongiform encephalopathy and possibly new substances due to mutations), are added to these problems.

In general, the dangers lurking on a cruise ship can be grouped into five main categories: personal hygiene, food, environmental causes, sexually transmitted diseases, and allergies (Moíp $\alpha$ \&

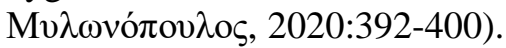

2.1.Personal Hygiene: is the main concern for the protection of every human being's health. Humans suffer from accidents and pollutants or infectious pathogens, which are inhaled or come in contact with the skin (especially the hands that come in contact with food) or are contained in the foods and beverages they consume. The measures taken aim at preventing accidents, excluding or restricting the entry into and contact of pathogens with the human body, along with vaccines, regular preventive blood tests, lung examinations, etc., which predict any damage and malfunctions of the organism in order to prevent diseases. Although most cruise ship passengers come from countries with national immunization programs (e.g. USA, Canada, United Kingdom), many crew members come from developing countries with lower vaccination coverage. This is the reason why cases of measles, rubella, meningitis and more often chickenpox, have been

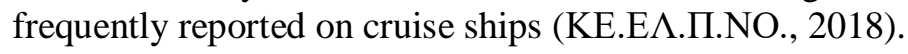

2.2. Foodborne Diseases: are those that are caused after eating food that has been contaminated with agents capable of causing disease under certain conditions. Of the various microbes and toxins that are considered to be causative agents of foodborne diseases, campylobacter, salmonella, and

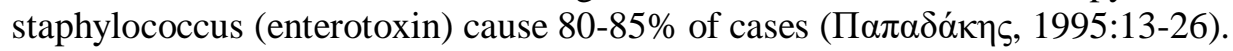

Food quality assurance requires special knowledge and handling of staff. An error in the chain of production - transport - maintenance - processing - preparation - exposure and disposal of food, can 
cause health problems to the consumer. Food safety and quality control by experts cannot be carried out on all quantities and varieties of food available for consumption, therefore, it is necessary to regularly and continuously inform food managers as well as consumers about quality control and hygienic food management, in order to limit or even avoid as far as possible the effects of consuming unsafe food.

The most commonly recorded health incident that has occurred on cruise ships is travellers' diarrhoea associated with foodborne illnesses (Bryant, et al., 1991; Mathews, Pust \& Cordes, 1991). A typical example is the outbreak of gastroenteritis on the cruise ship "Aurora", in 2003, where 430 people fell ill. The ship was carrying a total of 2,600 people (1,800 passengers and $800 \mathrm{crew})$. The virus was identified as the Norwalk virus, which usually occurs in places with poor hygiene such as cruise ships, hospitals, and schools and can contaminate water (The Guardian, 2003b). The panic was so great that in many ports - including those of Piraeus/Greece, Dubrovnik/Croatia and Venice/Italy, passengers were not allowed to disembark (Townsend, 2003; Henderson, 2007:106). Also, Spain, when the ship approached Gibraltar, closed the border crossing between Spain and Gibraltar for fear of transmission of the virus to the country's population (CNN, 2003).

Similar incidents took place on 10 different cruise ships during the year 2002, resulting in stomach disorders of approximately 1,400 passengers. In November-December 2017, during a 14/day cruise from Asia to Australia, an outbreak of norovirus occurred on the cruise ship "Ovation of the seas", affecting 195 passengers and crew members (Whiting, 2017). In January 2019, on the Royal Caribbean cruise ship "Oasis", which was sailing to Jamaica on a seven-day Caribbean cruise, there was a Norovirus outbreak that infected 592 passengers (561 travellers, 8.9\%, and crew members, $1.45 \%)$. The ship was forced to return to Florida for professional medical treatment of the infected passengers and crew (CBS News, 2019; Ware, 2019; CDC, 2019).

The storage of drinking water on a cruise ship is a critical and important process for the consumer's health. The supply of drinking water for the needs of a cruise ship comes from both municipal water supplies and private companies. An important concern of those responsible for the supply of drinking water for ships is to ensure its quality, not only by inspecting the certificates but also by running substantial additional analyses and tests. Metal tanks must be galvanized, without corrosion and with airtight canopy, but plastic tanks should be made of special durable material. In any case, drinking water storage tanks must be emptied at a regular basis, and their walls must be thoroughly cleaned and disinfected. The water distribution network in the areas of utilization must be regularly checked for any corrosion and leakage of water, in order toprevent the entry of pathogenic microorganisms in the water supply system that can lead to consumer contamination.

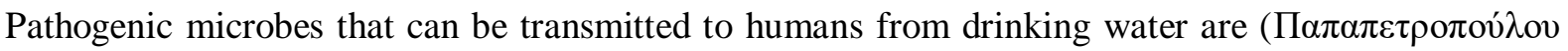

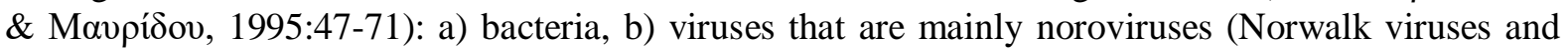
Rotavirus) that cause diarrhoea and gastroenteritis respectively and c) parasites that cause diarrhoea.

A large part (about $80 \%$ ) of the drinking water that is consumed on a cruise ship is bottled water, due to consumer distrust of the suitability of water on board. Although bottled water must be free of pathogenic microorganisms, according to existing legislation, in practice, this is not guaranteed, due to poor processing during bottling, transport, storage and disposal. Poor treatment of bottled water (storage conditions) on a ship impairs its quality. Research has shown (Fluvia et al. 1983:33-38; Caroli et al. 1985:461-464; Slade, Falah and Gkady 1986:471-476; Hunter and Bunger 1987:439-443;

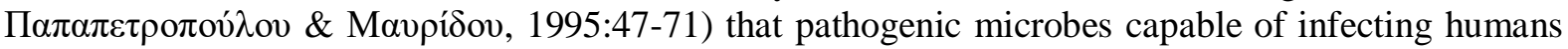
and causing disease have been found in bottled water. Amoebae (in Spain in 1983), acid-fast bacteria (in Italy in 1985), aeromontics (in Saudi Arabia in 1986) and staphylococci of human origin (in England in 1987) were the causal factors of epidemic outbreaks associated with bottled water.

Common mistakes and errors in food management that cause foodborne illnesses are due to lack of training of food managers, transport, storage, and preservation of food under poor conditions. They also occur due to food preparation and distribution by non-qualified personnel for issues on food management and public health, to lack or insufficient health check of employees working in the food sector, to poor conditions of food and other product distribution, and disinfection of food and feed areas, provision rooms, utensils, etc. Moreover, irregular testing of the drinking water quality and of the proper water supply network operation as well as ineffective observance of the regulations on 
insects and other infectious disease animals that can contaminate food or places of storage and food management are also causes of foodborne illnesses.

\subsection{Environmental Diseases.}

Many cruises often include restrictions on destinations where carriers of endemic diseases such as malaria, dengue fever, yellow fever, Japanese encephalitis and Zika or Chikungunya infections occur. In this case, in addition to vaccination, it is recommended that passengers should take precautionary measures (e.g. insect repellents, special clothing, etc.).

Also, furnished public spaces of a cruise ship are the locus of most germs, in both variety and quantity, from all sources and receptors of infection, and so they become the most probable infectious areas of the ship for all contagious diseases. The areas of dining, personal hygiene, water supply, sewerage and waste storage are the most critical ones for the growth of pathogenic microbes.

Continuous cleaning and disinfection of public spaces all day long, constitute a critical need on the crew's part. Incomplete or delayed disinfection of the ship's premises, when it exceeds twenty-four hours, is a dangerous negligence for the passengers' health. Cockroaches, for example, in addition to

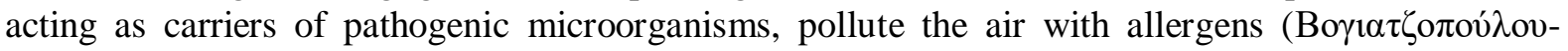



Air renewal and air conditioning of closed public spaces constitutes an essential prerequisite and hygiene rule, especially when these spaces are used by travellers of different geographical origin, cultural background, and unknown hygienic condition. Air conditioning of the premises can create a pleasant environment for the passengers and limit germ proliferation by cooling the area, yet, it may also favour the growth of other pathogenic germs, such as the legionella that causes pneumonia (Tsai, et al., 1989:509-517) with an incubation period of 2-10 days and a mortality rate of over 10\%, as well as atypical mycobacteria that cause pneumonia and lymphadenitis to young children (Jenkins \& Marks, 1971:60-66). Excessive use of air conditioners through overheating or cooling the public spaces may be the cause of harming instead of protecting human health.

In 1994, during 9 different cruise routes fifty passengers, one of whom died, became ill with legionnaires' disease on the cruise ship Horizon (Dickinson \& Vladimir, 1997:76; Jernigan, et al, 1996). It was later proved that the disease originated from the ship's air conditioning system (The Guardian, 2003b). Thus, it is recommended that overcrowding in enclosed spaces, where the air is not refreshed, and the ambient temperature exceeds $25^{\circ} \mathrm{C}$ should be avoided. Exposure to the airstream of the air conditioner, especially when our body is worn out from physical activity, should be avoided.

Cruise ship swimming pools usually have a small capacity in relation to the number of people that use them. Typically, the water used in swimming pools comes from the sea and may contain pathogenic microbes or allergens (phytoplankton and zooplankton biotoxins or pollutants) capable of causing health problems to humans (Fisher, 1988:397-398; Joce, et al, 1991:407-508; Jonckheere, 1985;

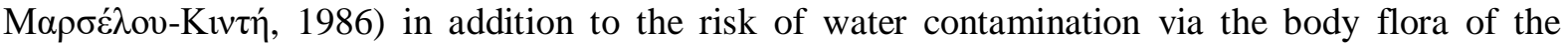
numerous swimmers. Each swimmer releases potentially pathogenic microorganisms from his/her


Prolonged use and stay of swimmers in the swimming pool in combination with the hot environment during the day may contribute to the proliferation of pathogenic microorganisms that may have attached to the skin or entered the oral cavity. For these reasons, the pools (tanks) must be regularly disinfected, chlorinated or constantly refreshed, while swimmers should take a shower with fresh drinking water immediately after bathing and before sunbathing to remove any infectious or toxic agents from their body.

\subsection{Venereal Diseases or Sexually Transmitted Diseases.}

Venereal diseases include syphilis, gonorrhoea, soft ulcer, inguinal lymphocytosis, inguinal granuloma, etc. and viral diseases such as acute warts, genital herpes, megalovirus infections, infectious mononucleosis, hepatitis B, Acquired Immune Deficiency Syndrome (AIDS), etc. (Daniels, et al., 1992)

Infectious agents of all these diseases can be easily spread among people when they come in physical or sexual contact with people who are carriers or sick. Sexual desireis more intense during recreation and tourist periods. Tourism, by nature, favours human communication and includes some elements 
that are indirectly related to human sexuality. A new social environment is created on the cruise ship, and conditions that may lead to behaviours among passengers on the one hand, and, on the other hand, between passengers and crew members, that are different and perhaps more flexible than usual. Vacation period, in general, and cruising, in particular, are considered the most dangerous for the infection of man with sexually transmitted pathogenic microbes, especially in casual sex relationships

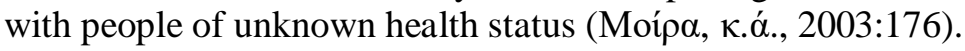

\subsection{Allergies.}

Common allergies that cruise ship passengers develop are due to three main factors: a) allergies to chemicals, such as detergent residues in linen and bathroom clothes that come in contact with the skin, certain soaps and disinfectants used for personal hygiene, volatile substances of various origin and aetiology, b) allergies to food and beverage ingredients. Allergy-causing food ingredients may be known or unpredictable for everyone. It is, therefore, imperative that in the restaurants and dining areas of the cruise ship there are menu boards, listing all constituents of the available foods and products, as far as food materials and additives are concerned, so that consumers can consult them and, thus, cases of allergies can be prevented or dealt with. c) allergies due to biological agents mainly fungi and parasites that are endemic to human skin and hair, carpets, fabrics, mattresses, wood and sewage. In general, every passenger who has allergies is obliged to inform the ship's Medical Centre.

\section{THE INTERNATIONAL CRUISING ENVIRONMENT}

Cruising is by nature an international activity, as it combines the entertainment of passengers from different geographical areas, with their visit to cosmopolitan ports around the world, satisfying the need to discover new places and come in contact with different cultures (Mv Therefore, cruising as a tourist activity is directly linked to the risk of infectious diseases with consequences that are not limited only to passengers on board but also extend to the countries where passengers disembark.

The confined space of a cruise ship, that facilitates the transmission of diseases, as well as the isolation at sea are the causes of phobia in potential passengers in the event of an epidemic. In addition, as cruise companies rely on pre-bookings, an outbreak can lead to cancellation of cruises and financial problems in the tourism industry.

The World Tourism Organization has set up an international network in order to help countries, tourist destinations, tourism staff and consumers respond successfully to health and safety issues in tourism. The purpose of the network "Health and Safety in Tourism" refers to the protection of life, physical and psychological condition, and economic situation of travellers, of those employed in tourism, and of the residents of host countries. It also includes issues on the protection and security of the countries of tourist origin as well as for the host countries, businessmen and tourism businesses. The system is based on the cooperation between organizations and experts on health and safety towards the goal of enhancing further the development of tourism. For this purpose, leaflets are issued, records and other necessary data related to public health and safety of tourists are kept (Moíp $\alpha$

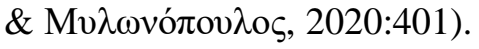

Each country undertakes the responsibility to implement the necessary measures in order to identify potential risks in tourism by type of travel, destination, and host region. Moreover, it adopts the necessary security measures and practices in tourist facilities and areas. It ensures continuous monitoring by experts with special attention to food safety, personal and public hygiene, and environmental safety.

It also ensures the existence of administrative bodies that will supervise compliance with health and safety legislation in tourist activities. National policies and services concerning hygiene matters are being developed. Special emphasis is given on information systems concerning travellers' health issues. Healthcare provision is also taken into consideration, so that both the travellers and the host country populations stay healthy. In Greece, the competent body is the National Public Health Organization (E.O.A.Y.).

\subsection{The Case of Coronavirus (Covid-19).}


In October 2019, the outbreak of a deadly coronavirus strain called COVID-19 was recorded. The coronavirus epidemic originated in the Chinese city of Wuhan, but it turned into a pandemic as it spread globally. Many countries, to control the spread of the virus, took a number of measures, among which was banning visitors/tourists from entering the affected areas. The result of the global turmoil was the restriction of tourist transportation, as governments issued travel advice ${ }^{1}$ warning their citizens to avoid traveling to China, while many countries closed their borders to tourists and travellers coming from affected areas in China. At the same time, Carnival and Costa Cruise companies cancelled all their cruises in China until early February. Also, the cruise ship "Spectrum of the Seas", which is the only cruise ship that has Shanghai as its home port, cancelled all scheduled cruises and returned the corresponding amount of money to the passengers (Bates, 2020). The Cruise Lines International Association (CLIA) stated that it is in cooperation with the World Health Organization in order to protect cruise passengers. These actions concern the modification of itineraries and the control of passengers and crew members coming from the affected areas as well as the prohibition of their boarding on cruise ships in case they are found to be ill (Taylor, 2020).

Characteristic is the incident recorded on the cruise ship "Costa Smeralda" in the port of Civitavecchia in Italy. When a Chinese passenger from Macau, who was thought to be infected with the dangerous coronavirus -which appeared in Wuhan, China- the port authorities did not allow the 7,000 passengers to disembark, fearing that the disease could be transmitted to the local population. After the embarkation of doctors, who examined the patients that had been quarantined by the ship's crew, and after the evidence that it was not a case of coronavirus, the passengers were allowed to disembark (Bubola, Povoledo and Horowitz, 2020).

"Carnival Diamond Princess" cruise ship is a special case of international mobilization. The cruise ship was on an eight-day cruise in Japanese ports, with a crew of 1,045 people and 2,666 passengers. On February 4, 2020, while was docked at the port of Yokohama, an inspection revealed that 10 passengers were tested positive for the coronavirus (Covid-19). The ship was quarantined, and its passengers and crew were banned from interactive communication with the shore. Passengers were isolated in their cabins. The international community mobilized for the repatriation of those passengers who were tested negative for the virus, as the passengers were of different nationalities (including two of Greek nationality). During the repatriation process, strict measures were taken to control the coronavirus and the repatriates were placed in a 14/day isolation/quarantine to prevent the transmission of the coronavirus to their country.

New Zealand's response to the spread of the coronavirus, which banned cruise ships from entering its territorial waters from 14 March 2020 to 30 June 2020 (New Zealand Immigration, 2020), is also characteristic.

The cruise industry proved to be unprepared to face the coronavirus crisis. When cases were confirmed, passengers of cruise ships were found trapped at sea. By March 2020, coronavirus outbreaks had been confirmed on at least 25 cruise ships around the world (Mallapaty, 2020:18), banning them from arriving at any port, for fear of spreading the virus to the general population. According to available data, a total of 3,170 people (passengers and crew) was infected with Covid-19 coronavirus, of which 69 died. In March 2020, all major cruise companies suspended their operations for a period of 30-60 days. The suspension came as a result of a lack of infrastructure, increased travel restrictions and the consequent travellers' phobia. The US Centre for Disease Control and Prevention (CDC) announced lifting its no-sail order on cruises. Of course, all major cruise companies have ceased operations until the end of 2020. On the contrary, European cruise companies (such as MSC Cruises and Costa) have resumed operations in the Mediterranean.

After the end of the first coronavirus wave, cruise companies tried to find solutions so that cruising could recover. An innovative solution is the "Cruise to Nowhere" that was announced by Singapore and will take place with the "World Dream" of Genting Cruise Lines and the "Quantum of the Sea" of

\footnotetext{
${ }^{1}$ Travel advices or advisories are issued by a governmental or an international body that draws the travelers' attention to concrete destinations for a number of reasons, like armed violence, popular revolutions or political unrest, high crime rates..., natural disasters or outbreaks of contagious diseases. The travel advisories are, most of the times, issued by the states and addressed to the citizens who intend to travel or already are abroad

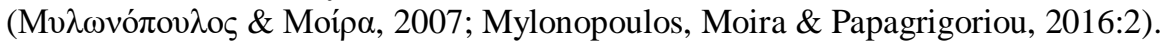


the Royal Caribbean. Cruising will be different, as the ships will depart from home port and will return to the same port without stops in ports of call. In addition, only citizens of Singapore will be able to travel. Strict health protocols are provided to ensure the travellers' health. Passengers and crew must have been tested negative for coronavirus in order to board. The carrying capacity of the ships will be limited to $50 \%$. During the voyage, indoor air will be replaced with fresh air, and passengers, when not in their cabins, will wear a mask (Choudhury, 2020). With this "pilot cruising", companies seek to redefine entirely the voyage on board experience, and, in addition, regain the passengers' trust.

Finally, Greece, in order to prevent the entry of passengers infected with the coronavirus, issued a Joint Ministerial Decision, which temporarily prohibited the arrival of cruise ships at Greek ports for precautionary reasons, in order to protect public health from the spread of the coronavirus in Greek territory with a validity period from $15 / 3 / 2020$ to $15 / 4 / 2020$. The ban on the arrival of cruise ships at Greek ports was extended until 01/6/2020. Currently, a new ban is applied from 7/11/2020 till $30 / 11 / 2020$.

\section{CONClusion}

The modern cruise ship, as a means of public transport, is an ideal place for the collection, proliferation and spread of almost all pathogenic infectious microbes.

The multifactorial dimension of the occurrence of infectious diseases on a cruise ship requires strict compliance with hygiene rules by both passengers/travellers and crew members. The same obligation applies to those who trade in various ways with the cruise ship. Nowadays, this claim becomes imperative as a cruise ship is not just a luxurious floating hotel but a floating leisure resort as well

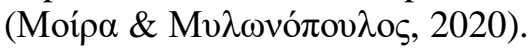

The complexity of the consequences of the occurrence of infectious diseases on a cruise ship goes beyond the narrow boundaries of the infected area and requires action not only at a private level on the part of the company, but also at national and international levels. The multicultural environment of a cruise ship, which characterizes both the crew and the passengers, requires that a high level of hygiene measures be implemented. This can be achieved through international cooperation on health and safety in the field of cruising. In addition, rational management of health crises through the operation of an organized company department, staffed with various scientific specialties, is imperative.

The rational management and operation of health services and nursing care on a cruise ship along with lockdown - quarantine imposed spatially, makes it possible to manage the Covid-19 pandemic.

Strict observance of proper hygiene practices contributes to the continuation of cruising as a maritime tourist activity.

\section{REFERENCES}

[1] Bates, A. (2020). How Coronavirus Could Play Out for Cruise Operators, Barron's, February 1, at https:/ /www.barrons.com/articles/how-coronavirus-could-play-out-for-cruise-operators-51580561100

[2] Bryant, H.E. - Csokonay, W.M. - Love, M. \& Love, E.J. (1991). Self-reported illness and risk behaviors amongst Canadian travelers while abroad, Canadian Journal of Public Health, 82(5), pp. 316-319.

[3] Bubola, E. - Povoledo, E. \& Horowitz, J. (2020). Cruise Passengers Are Held at Italian Port in False Alarm Over Coronavirus, NYTIMES,30 January, at https://www.nytimes.com/2020/01/30/world/europe/ italy-coronavirus-cruise.html

[4] Caroli, G.-Levre, E.-Armani G.-Biffi-Gentili, S. \& Molinari, G. (1985). Search for acid-fast bacilli in bottled mineral waters. Journal of Applied Bacteriology, 58, pp. 461-464.

[5] CBS News (2019). Norovirus outbreak sickens hundreds of cruise ship passengers, crew members, 11 January, at https://www.cbsnews.com/news/norovirus-outbreak-hits-royal-caribbean-cruise-ship-277-peop le-sick-passengers-crew/

[6] CDC (2014). Facts about noroviruses on cruise ships, U.S. Department of Health \& Human Services, at https://www.cdc.gov/nceh/vsp/pub/norovirus/norovirus.htm

[7] CDC (2019). Investigation Update on the Oasis of the Seas, Centers for Disease Control and Prevention, January 10, at https://www.cdc.gov/nceh/vsp/surv/outbreak/2019/Oasis_of_the_Seas_1-6.html

[8] CLIA (2015). Annual Report, at https://www.cruising.org/docs/default-source/market-research/clia_2015_ annualreport_web.pdf?sfvrsn $=0$

[9] CLIA (2019). Cruise Trends and Industry Outlook, at https://cruising.org/news-and-research/-/media/ CLIA/Research/CLIA-2019-State-of-the-Industry.pdf 
[10] CNN (2003). "Flu ship' leaves, border reopens", CNN News, November 4, at http://edition.cnn.com/2003/ WORLD/europe/11/03/spain. gibraltar/index.html

[11] Choudhury, S.R. (2020). After Singapore greenlights cruises to nowhere, Genting's Dream Cruises says inquiries are 'coming nonstop', October, 9th, $C N B C$,https://www.cnbc.com/2020/10/09/gentings-dreamcruises-on-cruises-to-nowhere-program-in-singapore.html

[12] Daniels, D.G., Kell, P., Nelson, M.R. \& Barton, S.E. (1992). Sexual behavior amongst travelers: A study of genitourinary medicine clinic attendees, International Journal of STD \& AIDS, 3(6), pp. 437-438.

[13] Dickinson, R.H. \& Vladimir, A.N., (1997). Shelling the Sea. An Inside look at the cruise industry. New York: John Wiley \& Sons, Inc.

[14] Ewan, C. - Bryant, E. \& Calver, D. (1991). Health implications of long-term climatic change. A report of the National Health and Medical Research Council. Canberra: Australian Government Publishing Service.

[15] Fisher A.A. (1988). Swimming pool granulomas due to Mycobacterium marinum: an occupational hazard of lifeguards. Cutis, 41(6), pp. 397-398.

[16] Fluvia, C. - Mascaro, C. \& Perez, M.I. (1983). Evolution of the population of limax Amoebae protozoa Lobosea in bottled water, influence of time of storage. Rev. Iber. Parasitol, 43(2), pp. 33-38.

[17] Foster, D. (1994). First Class: An Introduction to Travel and Tourism, McGraw-Hill International Editions.

[18] Fujimori, H. \& Shimura, M. (1987). Meteorological factors and psychiatric emergency admission. In: Miura TW (ed) Seasonal Effects on Reproduction, Infection and Psychoses. The Netherlands: SPB Academic.

[19] Goldstein, B.D. \& Reed, D.J. (1991). Global atmospheric chance and research needs in environmental health sciences. Environmental Health Perspectives, 96, pp. 193-196.

[20] Henderson, J.C. (2007). Managing Tourism Crises, Butterworth-Heinemann.

[21] Hunter, P.R. \& Bunger, S.H. (1987). The bacteriological quality of bottled natural mineral waters. Epidemiology and Infection, 99(2), pp. 439-443.

[22] Jenkins, P.A. \& Marks, J. (1971). Transient colonisation of the respiratory tract by mycobacteria in south Wales. Tubercle, 52(1), pp. 60-66.

[23] Jernigan, D.B. - Hofmann, J. - Cetron, M.S. - Genese, C.A. - Nuorti, J.P. - Fields, B.S. - Benson, R.F. Carter, R.J. - Edelstein, P.H. - Guerrero, I.C. - Paul, S.M. -Lipman, H.B. \& Breiman, R. (1996). Outbreak of Legionnaires's disease among cruise ship passengers exposed to a contaminated whirlpool spa. The Lancet, February 24, 347(9000), pp. 494-499.

[24] Joce, R.E. - Bruce, J. - Kiely, D. - Dempster, W.B. - Stalker, R. - Gumsley, P. - Champan, P.A. Watkins, J. - Smith, H.V. - Price, T.J. \& Watts, D. (1991). An outbreak of cryptosporidiosis associated with a swimming pool, Epidemiololy and Infection, 107(3), pp. 497-508.

[25] Jonckheere, J.F. (1985). Aemoebae in public swimming pools. International Seminar on Technical, Hygienic and Health Problems in the Issue of Public Health Swimming Pools. Denmark: Herning.

[26] Jones, P. - Hillier, D. \& Comfort, D. (2016). The Environmental, Social and Economic Impacts of Cruising and Corporate Sustainability Strategies, Athens Journal of Tourism, 3(4), pp. 273-285.

[27] Mallapaty, S. (2020). What the cruise-ship outbreaks reveal about COVID-19. Nature, 580, at https://www.nature.com/articles/d41586-020-00885-w

[28] Mathews, D.S. - Pust, R.E. \& Cordes, D.H. (1991). Prevention and treatment of travel-related illness, American Family Physician, 44(4), pp. 1343-1358.

[29] Mylonopoulos, D. - Moira, P. \& Papagrigoriou, A. (2016). The Travel Advisory as an Obstacle to Travel and Tourism. Case Study-The Greek Economic Crisis, International Journal of Research in Tourism and Hospitality (IJRTH), 2(2), pp. 1-13 http://dx.doi.org/10.20431/2455-0043.0202001

[30] New Zealand Immigration (2020). INZ response to the Covid-19 (Novel Coronavirus), at https://www. immigration.govt.nz/about-us/media-centre/news-notifications/coronavirus-update-inz-response?

[31] Rieth, H. (1985). Mycological problems in public swimming pools. International Seminar on technical, hygienic and health problems in the issue of public health swimming pools. Denmark: Herning.

[32] Rooney R.M. - Bartram, J.K. - Cramer, E.H. - Mantha, S. - Nichols, G. - Suraj, R. \& Todd E.C. (2004). A review of outbreaks of waterborne disease associated with ships: evidence for risk management. Public Health Reports, 119(4), pp. 435-442.

[33] Sawchuk I.A. (1993). Societal ecological determinants of urban health: a case study of prereproductive mortality in 19th century Gibraltar. Social Sciences and Medicine, 36(7), pp. 875-892.

[34] Slade, P.J. - Falah, M.A. \& Gkady, A.M.R. (1986). Isolation of Aeromonas hydrophyla from bottled waters and domestic water supplies in Saudi-Arabia. Journal of Food Protection, 49(6), pp. 471-476.

[35] Starr, N. (1993). Viewpoint. An Introduction to Travel, Tourism and Hospitality, Houghton Mifflin Company. 
[36] Tardivel, K. - White, St.B. - Kornylo Duong, Kr. (2019). Travel by Air, Land \& Sea, Cruise Ship Travel, at https://wwwnc.cdc.gov/travel/yellowbook/2020/travel-by-air-land-sea/cruise-ship-travel

[37] Taylor, C. (2020). Cruise ships screen passengers and change routes to battle coronavirus threat, $C N B C$, January 31, at https://www.cnbc.com/2020/01/31/coronavirus-international-cruise-lines-implementprecautionary-steps.html

[38] The Guardian (2003a). Virus-hit cruise ship receives emergency aid, October 31, at https://www.thegua rdian.com/uk/2003/oct/31/travelnews.travel

[39] The Guardian, (2003b).The stomach bug on board the cruise liner Aurora has struck down a quarter of the passengers and caused an international incident. But is the risk that great - and are ships breeding grounds for such outbreaks?, November, 4th, at https://www.theguardian.com/lifeandstyle/2003/ nov/04/healthandwellbeing.health

[40] Townsend, M. (2003).Safe port in sight for cruise ship passengers hit by stomach bug, The Observer, November 2, at https://www.theguardian.com/travel/2003/nov/02/travelnews.medicineandhealth.uknews

[41] Tröhler, U. (2003). James Lind and scurvy: 1747 to 1795. JLL Bulletin: Commentaries on the history of treatment evaluation, at https://www.jameslindlibrary.org/articles/james-lind-and-scurvy-1747-to-1795/

[42] Tsai, T.F. - Finn, D.R. - Plikaytis, B.D. - McCauley, W. - Martin, S.M. \& Fraser, D.W.(1989). Legionnaires' disease with clinical features of the epidemic in Philadelphia. Annals of Internal Medicine, 90(4), pp. 509-517.

[43] Walsh, J. - Molyneux, D. \& Birley, M. (1993). Deforestation: Effects on vector-borne disease. Parasitology, 106 (S1), suppl: S55-S75.

[44] Ware, G. (2019). Norovirus outbreak on Royal Caribbean cruise ship sickens 475 passengers, January, 11th, $A B C$ News, at https://abcnews.go.com/US/270-cruise-ship-passengers-sickened-norovirus-royalcaribbean/story?id=60291868

[45] Whiting, N. (2017). Gastro outbreak on Ovation of the Seas cruise ship, almost 200 ill, ABC News, December, 5th, at https://www.abc.net.au/news/2017-12-05/gastro-outbreak-on-ovation-of-seas-cruiseship/9226346

[46] WHO (2003). Climate change and human health - risks and responses. Summary. World Health Organization, at https://www.who.int/globalchange/summary/en/

[47] WHO (2011). Guide to ship sanitation (third edition). Global reference on health requirements for ship construction and operation, April, World Health Organization, 2011, at https://www.who.int/water_ sanitation_health/publications/2011/ship_sanitation_guide/en/

[48] WHO/SDE/WSH/01.4 (2001). Sanitation on ships: compendium of outbreaks of foodborne and waterborne disease and Legionnaires's disease associated with ships, 1970-2000 at http://www.who.int /water_sanitation_health/diseases/shipsancompendium/en/

[49] Wood, R. (2000). Caribbean Cruise Tourism, Globalization at Sea, Annals of Tourism Research, 27(2), pp. 345-370.

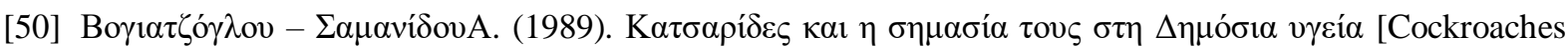

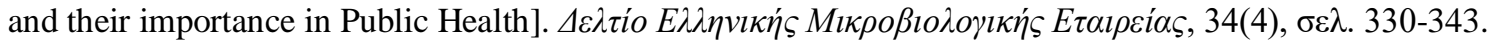

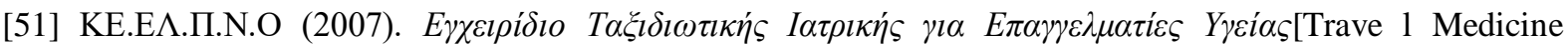



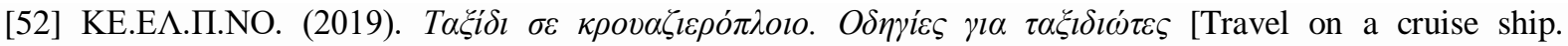
Instructions for travelers]. $\sigma \tau$ o https://eody.gov.gr/wp-content/uploads/2019/01/taksidi_se_kroyazieroploio odigies_gia_taksidiotes.pdf [in Greek].

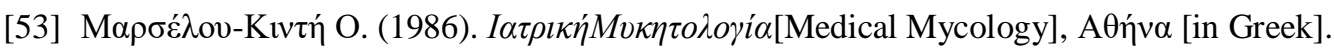

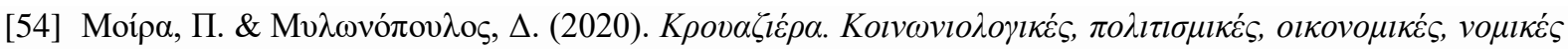
$\& \pi \varepsilon \rho \iota \beta \alpha \lambda \lambda о v \tau \imath \kappa \varepsilon ́ \varsigma$ $\pi \rho о \sigma \varepsilon \gamma \gamma i \sigma \varepsilon l \varsigma$ [Cruise. Sociological, cultural, economic, legal \& environmental

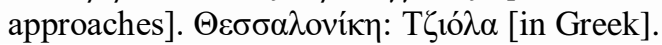

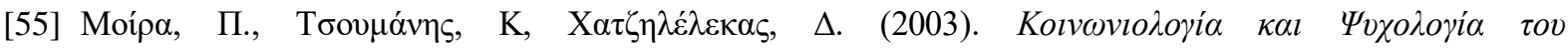

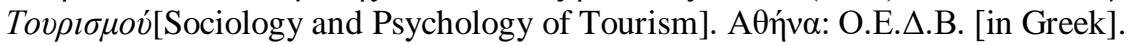

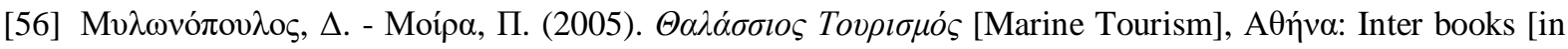
Greek].

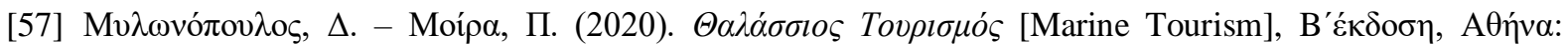
$\Phi \alpha i ́ \delta$ os [in Greek].

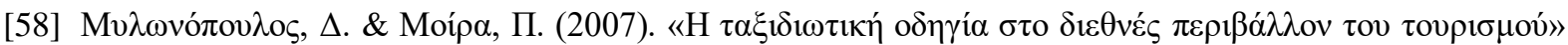

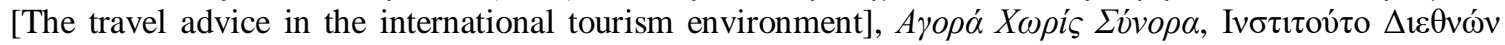

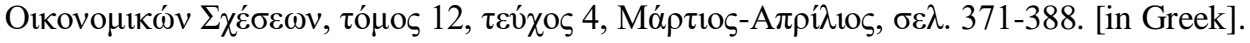

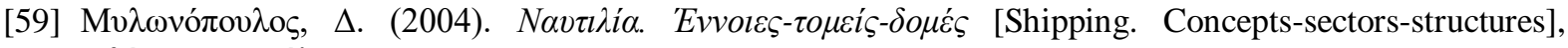

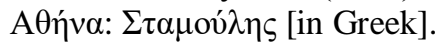




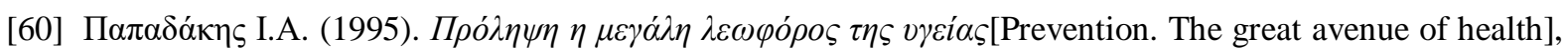

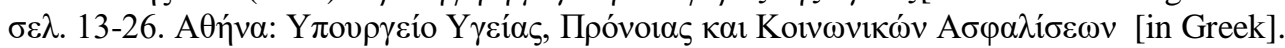

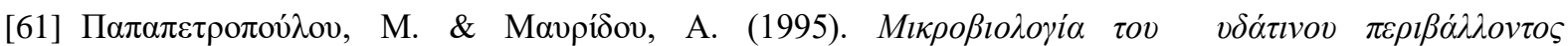

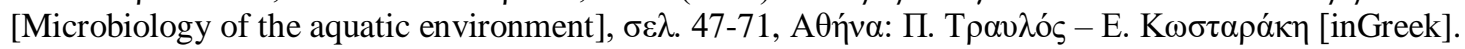

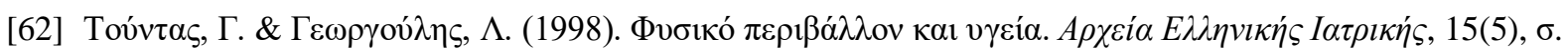
482-493. [in Greek].

\section{AUTHOR'S BIOGRAPHY}

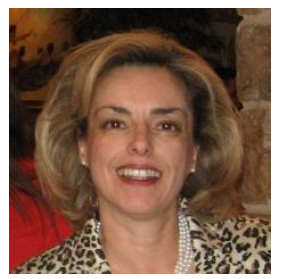

Polyxeni Moira, holds a PhD in Sociology from Panteion University of Political and Social Sciences, Greece. She has BA degrees a) in Public Administration, b) International and European Studies and c) Communication and Mass Media. She also holds an MSc in Regional Development and Pedagogy. She has been teaching at higher education over the last 12 years. She is currently a Professor at the Department of Tourism Management at the University of West Attica in Greece. She is also a Visiting Professor at the University of Ioannina, at Harokopeion University, at University of Aegean and the Hellenic Open University. She has published more than 15 scientific books in the field of tourism and articles in international and Greek journals.

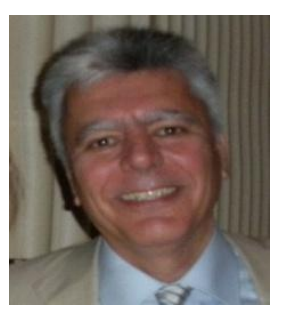

DimitriosMylonopoulos, holds a $\mathrm{PhD}$ in Public Law from Panteion University of Political and Social Sciences, Greece. He has studied at Democriteion University of Thrace, Panteion University, Harokopeion University, Economic University of Athens, National and Kapodistrian University of Athens and Hellenic Navy Academy. He holds BA degrees a) in Law, b) in Public Administration, c) in International and European Studies and d) in Communication and Mass Media. He also holds a) MSc in Applied Geography and Area Management, b) in Pedagogy, c) in European Studies, d) in Maritime Studies and e) in Promotion of Mental Health and Prevention of Mental Disorders. He has been teaching at higher education over the last 20 years. He is retired senior officer in Hellenic Coast Guard. He is currently Professor at the Department of Tourism Management at the University of West Attica (Greece). He is also a Visiting Professor at the University of Patras, at University of Aegean, at Hellenic Army Academy, at Hellenic Naval Academy and at Hellenic Open University. He has published scientific books in the field of tourism and maritime issues and articles in international and Greek journals.

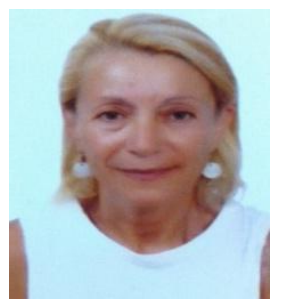

Elli Terzoglou, is Assistant Professor of English for Specific Purposes at the Department of Tourism Management of the University of West Attica. She holds a $\mathrm{BA}$ in English Language and Literature from the Aristotle University of Thessaloniki, a BA in History from the University of Ioannina and an MA in Linguistics (TESOL) from the University of Surrey, England. She has been a member of the higher education academic staff for the last 35 years, teaching English for Specific Purposes to different specialties. She has published two English Grammar Books, she has written training manuals for English for Aircraft Electricians and Airplane Armourers for the Schools of the Hellenic Air Force. She has participated in international conferences and published articles in international and Greek journals in the field of tourism.

Citation: Polyxeni Moira, Dimitrios Mylonopoulos, Elli Terzoglou. "Hospitality Health Issues and Cruising in Covid-19 Era". International Journal of Research in Tourism and Hospitality (IJRTH), vol 6, no. 3, 2020, pp. 12-22. doi: https://doi.org/10.20431/2455-0043.0603002.

Copyright: () 2020 Authors. This is an open-access article distributed under the terms of the Creative Commons Attribution License, which permits unrestricted use, distribution, and reproduction in any medium, provided the original author and source are credited. 